\title{
Predictors of Daily Deal Customers' Loyalty in the Restaurant Industry
}

\author{
By Jue Huang* \\ Chun-yu Yang ${ }^{\dagger}$ \\ Lingli Yuan
}

Online group buying is a growing fashion among consumers, especially in the restaurant industry. However, customer loyalty in the context of this new business model was a neglected research area. With a survey of daily deal customers, this study examined predictors of customer loyalty in the restaurant industry in China. Besides perceived value and satisfaction, which were well-established predictors in the marketing literature, the study included several variables that reflected the unique experiential aspects of the daily deal offerings. Specifically, the results indicated that customers with higher intention to repurchase were those who were less deal prone and those who thought less of a restaurant because of its offering of daily deals.

Keywords: Customer Loyalty, Daily Deals, Deal Prone, Perceived Value, Restaurant Industry.

\section{Introduction}

As a new business model, daily deals have become a rapidly growing phenomenon in the e-commerce world. The term daily deal was often used interchangeably with group buying. Daily deals offered products for sale for a limited time and usually provided large discounts if a pre-determined number of consumers agreed to purchase it (Grewal et al. 2011). Typical product categories on sale usually included restaurants, spas and other entertainment options, which consumers were generally familiar with or have some knowledge of the service providers (Grewal et al. 2011). Similar observation was made in China. For instance, Ning and Zhang (2011) found that the top categories of group buying were restaurants and leisure/recreational services, purchased respectively by $57.8 \%$ and $38.1 \%$ of the respondents.

Despite the diffusing of the information technology, small and medium enterprises were still lagging behind to tap the potential of the Internet. With group buying, intermediaries allowed local merchants to utilize the Internet technology and localized online advertisements in ways previously unavailable to small merchants (Lee and Lee 2012). The intermediaries provided impetus to the digitalization of small firms, by providing branded e-commerce platforms with access to potential customers (Enfodesk 2013). According to

\footnotetext{
* Assistant Professor, United Arab Emirates University, UAE.

${ }^{\dagger}$ Professor, Guizhou University of Finance and Economics, China.

* Undergraduate Student, Guizhou University of Finance and Economics, China.
} 
Enfodesk (2013), beside the motivation on the part of the businesses to tap the potentials of e-commerce, there was another reason for the rapid growth of daily deals in China. Namely, the increasingly well-to-do Chinese consumers' quest for quality and diversified local services to improve their everyday life. Group buying was introduced into China in 2009 and by the end of 2014, the number of group buying consumers has reached 173 million, representing $26.6 \%$ of all online consumers in China (CNNIC 2015).

\section{Literature Review}

Although the daily deal business has become a prominent aspect of consumer life, there was a paucity of study in this area (Lee and Lee 2012, Parsons et al. 2014, Zhang et al. 2013). A review of the literature conducted by Wang and Liu (2013) found that overseas researchers focused mainly on three areas, including consumer behavior, business models and auction mechanism and strategies of online group buying. In mainland China, the business practice of group buying contained only one pricing model, namely, the fixed pricing mechanism. Thus, auction and related pricing issues were almost nonexistent in the Chinese literature. The limited empirical study focused primarily on consumer behavior and qualitative evaluation about the business models was the second most common research stream (Wang and Liu 2013). The following presented a review of the literature on consumer behavior in group buying, which was of primary relevance to the current study.

Current research on consumer behavior in group buying predominantly focused on willingness to purchase and factors influencing consumer choices. For example, Parsons et al. (2014) examined factors that influenced shoppers' choices, quality perceptions and purchase likelihood. These factors included design of the deals (e.g., discounting levels and deal size), customer characteristics and offer type (product or service). Customers' personality traits (desire for conformity/uniqueness) and brand familiarity had compounding effects on the design factors. Li et al. (2012)'s results revealed that time pressure (i.e., time remaining before the deal expires) and reference group (i.e., number of deals sold) had positive effects on consumers' willingness to purchase. Moreover, consumers' personality traits - impulsiveness - moderated the effects. Similar study was done by Ning and Zhang (2011). Furthermore, the technology acceptance model (TAM) was the commonly used theoretical foundation to predict consumer willingness to purchase (e.g., Zhang and Lu 2009, Zhang et al. 2012) and consumer trust was another explanatory variable under investigation (e.g., Zhang et al. 2012).

In general, current report confirmed daily deals' usefulness as a promotion tool to raise brand exposure to the market place. Study by Zhang et al. (2013) confirmed that generous discounts could bring in more customers. However, despite the widely recognized market penetration function of daily deals, the profitability of this practice was questioned (Grewal et al. 2011). In fact, anecdotal reports about businesses losing money from their deal offerings were 
not uncommon. This happened primarily due to cannibalization, with lower than average check customers replacing existing, full-paying customers (Wu et al. 2012). As commented by Grewal et al. (2011), little was known about the effectiveness of this relatively new form of price promotion model. Given the deep discount that firms often provided to attain adoption on the part of the consumers, the profitability of daily deals depended on whether an initial trial by customers would gain repeat purchase over time (Parsons et al. 2014). Thus, it was imperative to examine the behavioral intention or loyalty of group buying customers.

However, very limited empirical study has focused on this topic. An exception was made by Zhang et al. (2013). The authors found that group buying effectiveness (represented by customers' return intention and several other variables) was affected by discount rate, service quality and popularity of restaurants. In the general services marketing literature, service quality, satisfaction and perceived value were widely used predictors of customer loyalty (Baker and Crompton 2000, Petrick 2004). Nevertheless, an investigation of group buying customers' behavioral intention needed to consider factors that were peculiar to this type of business model. Intention to return could be jeopardized by customer experience that was unique to this type of offerings. For example, one experiential aspect was customers' perceived risk of discrimination on the part of the merchandisers. Study by Tan (2013) revealed that $30.95 \%$ of the respondents had the experience of being treated like second class citizens because they were using daily deals. The study by Kimes and Dholakia (2011) was exceptional in that it investigated customers' evaluation of their daily deal experience, covering aspects that were peculiar to this type of business model. These included customers' perception of service experience (e.g., treated like second class citizen) and reliance on the deal (e.g., will not return without the deal).

\section{Research Objectives and Hypothesis}

Borrowing the 10-items scale of restaurant daily deal evaluation developed by Kimes and Dholakia (2011), this study aimed to examine factors that influenced group buying customers' intentional loyalty. Behavioral intention was measured with two commonly used variables, including intention to recommend and to repurchase without a deal. The scale included five categories of predictors, including service experience, spending and ordering behavior, deal prone, perceived value and overall satisfaction. Deal prone measured the personality traits of customers' reliance on the deal/discount. The questions were measured with a 7-point Likert scale, from 1=strongly disagree to $7=$ strongly agree.

The literature generally supported the impact of customer satisfaction, perceived value and service quality or service experience on customer loyalty (Baker and Crompton 2000, Petrick 2004). Among the limited studies of group buying consumers' behavior, Zhang et al. (2013) confirmed that larger discounts 
could generate more customer traffic and higher sales for restaurant services. This was consistent with the study by Kimes and Dholakia (2011), who observed that group buying customers were generally value conscious. Thus, perceived value could have positive impact on group buying customers' loyalty. Based on the foregoing discussion, the following hypotheses were proposed:

- H1: Overall satisfaction will have a positive impact on customer loyalty.

- H1a: Overall satisfaction will have a positive impact on customer intention to repurchase.

- H1b: Overall satisfaction will have a positive impact on customer intention to recommend.

- H2: Higher (lower) perceived value will lead to higher (lower) levels of customer loyalty.

- H2a: Higher (lower) perceived value will lead to higher (lower) levels of customer intention to repurchase.

- H2b: Higher (lower) perceived value will lead to higher (lower) levels of customer intention to recommend.

- H3: Positive evaluations of service experience will have a positive impact on customer loyalty.

- H3a: Positive evaluations of service experience will have a positive impact on customer intention to repurchase.

- H3b: Positive evaluations of service experience will have a positive impact on customer intention to recommend.

A significant study by Knox and Denison (2000) revealed that while loyal customers tended to have smaller monthly budgets than switchers, they spent double the amount in their first choice store. However, causality between spending and loyalty is not obvious. Spending may be an antecedent of loyalty. The rationale behind this is that when people buy more from a provider, they tend to stick to the same provider due to inertia or because they gradually build up their attachment to the provider. On the other hand, people may need to develop more attachment with a provider before they spend more with it. For example, Back and Parks (2003) revealed that attitudinal brand loyalty led to behavioral brand loyalty. Similarly, Reinartz et al. (2008) confirmed that crossbuying was a consequence and not an antecedent of behavioral loyalty. However, because the dependent variable in the current study was intentional loyalty (not behavioral loyalty), it was proposed that current spending and ordering behavior would have positive impact on future behavioral intention. Thus, the following hypotheses were proposed:

- H4: Higher (lower) levels of spending and ordering behavior will lead to higher (lower) levels of customer loyalty.

- H4a: Higher (lower) levels of spending and ordering behavior will lead to higher (lower) levels of customer intention to repurchase. 
- H4b: Higher (lower) levels of spending and ordering behavior will lead to higher (lower) levels of customer intention to recommend.

Finally, Kimes and Dholakia (2011) found that daily deal purchasers had a higher propensity to use coupons than non-purchasers. They were coupon prone, for whom a coupon was a sign of a good deal. Given the deep discount that was common in daily deals, it was posited that consumers who relied more on daily deals would be less likely to return without the deal. However, given the same level of service experience and satisfaction, there were no theoretical foundations to posit that coupon or deal proneness would affect customers' intention to recommend. Therefore, a hypothesis was proposed for intention to repurchase:

- H5: Deal proneness will have a negative impact on intention to repurchase.

\section{Methodology}

An online questionnaire was designed and a convenience sample was collected through referral of friends and relatives from January to February 2015. The daily deal evaluation scale was translated into Chinese independently by two authors and the difference in translation was discussed and resolved. Respondents who had restaurant group buying experiences were invited to answer the survey. About 25 cases had uniform answers for all of the questions in scale. Such cases were deemed unacceptable and excluded from the analysis. To enhance the authenticity of the data, if there were multiple responses from the same IP address, only the first response was included in the analysis. Screening of the data resulted in a qualified sample size of 100 . The sample size was acceptable based on the general rule of thumb of 10 cases for each predictor.

The study employed the following statistical methods for data analysis. First, descriptive statistics were presented to reveal the characteristics of the respondents' demographic profile and the property of the variables related to daily deal evaluation. Second, before testing the hypothesis, the dependent and independent variables were examined for their construct reliability (as measured by the Cronbach's Alpha) and correlation coefficients. Finally, hierarchical regression analysis was conducted to test the hypotheses. This method was preferably to other regression methods because it allows the researchers' to evaluate the contributions of predictors above and beyond previously entered predictors, as a means of statistical control. It also adds to the understanding of the phenomena being studied by the researchers' thoughtful input in determining the order of entry of the independent variables (Lewis 2007). In the present study, the demographic variables were entered first as the control variables. Then, based on the results of previous study, the relatively established predictors of customer loyalty (including overall satisfaction, perceived value and service experience) were modeled sequentially. Finally, the less researched variables related to group buying behaviors (e.g., spending and ordering behavior and deal proneness) were entered in the model. 


\section{Study Sample and Data}

Table 1 shows the respondents' demographic background. The sample consisted primarily of people between the age of 18 and $29(91 \%)$ and about $35 \%$ were students, followed by business firm employees (24\%). Although this was a convenience sample not intended to mirror the population, the sample profile was coincidentally similar to other studies. For instance, in a survey by Ning and Zhang (2011), 89.3\% of the respondents aged between 18 and 29, 82.6\% were university students and $12.1 \%$ were company employees. However, although Enfodesk (2014) reported similar distribution of age, it had a profession profile predominated by employees of government institutions and business firms $(80.2 \%)$.

Table 1. Respondents' Demographic Profile

\begin{tabular}{|l|l|c|}
\hline & & Sample (\%) \\
\hline Gender & Male & 57 \\
\hline Age & Female & 43 \\
\hline & Below 18 & 6 \\
\hline & $18-29$ & 91 \\
\hline Education & $30-39$ & 3 \\
\hline & High school and lower & 16 \\
\hline & Associate degree & 41 \\
\hline Profession & Bachelor degree and above & 43 \\
\hline & Student & 35 \\
\hline & Business & 24 \\
\hline Monthly income (RMB) & Others & 41 \\
\hline & Below 1,000 & 18 \\
\hline & 1,000 to 2,000 & 24 \\
\hline & 2,001 to 3,000 & 24 \\
\hline & 3,001 to 5,000 & 26 \\
\hline
\end{tabular}

Source: Authors' estimations.

Descriptive statistics for the variables are presented in Table 2. Behavioral intention and deal prone were constructs with two indicators respectively and their construct reliability as measured by Cronbach's Alpha was 0.764 and 0.653 respectively. The other categories of predictors tapped different aspects of the customers' daily deal experience (e.g., spending more and ordering more than usual) and there was no theoretical basis to suggest the unidimensionality of the items within each category. Thus Cronbach's Alpha was not computed for them. Note that two variables representing service experience (V3 and V4) were negatively worded, hence they were reverse coded before submitted to the correlation and regression analyses. V3 and V4 had negative correlation with all the other variables, with coefficients ranging from -0.584 to -0.234 . These negative coefficients were expected, because theory in consumer behavior generally suggests that negative perception of the service experience leads to lower levels of satisfaction, perceived value, loyalty intention and spending and ordering behavior. All of the other correlation coefficients were positive, ranging from 0.188 to 0.747 (Table 3 ). 
Table 2. Descriptive Statistics for Daily Deal Evaluation Variables

\begin{tabular}{|c|c|c|c|c|c|}
\hline Concepts and Items & Mean & Std. Dev. & Skewness & Kurtosis & $\begin{array}{c}\text { Cronbach's } \\
\text { Alpha }\end{array}$ \\
\hline Spending and ordering behavior & & & & & - \\
\hline $\begin{array}{l}\text { V1. I spent more at this restaurant } \\
\text { than I usually spend for a meal } \\
\text { when eating out. }\end{array}$ & 4.00 & 1.990 & -0.031 & -1.067 & \\
\hline $\begin{array}{l}\text { V2. I ordered more items than I } \\
\text { usually do because I was using the } \\
\text { daily deal. }\end{array}$ & 4.41 & 1.776 & -0.235 & -0.744 & \\
\hline Service experience & & & & & - \\
\hline $\begin{array}{l}\text { V3. During my visit, I was treated } \\
\text { like a second class citizen because I } \\
\text { used the daily deal. }\end{array}$ & 4.30 & 1.977 & -0.220 & -1.155 & \\
\hline $\begin{array}{l}\text { V4. The fact that this restaurant } \\
\text { offered a daily deal makes me think } \\
\text { less of it. }\end{array}$ & 3.46 & 1.997 & 0.258 & -1.086 & \\
\hline Deal prone & & & & & 0.653 \\
\hline $\begin{array}{l}\text { V5. I would not have gone to this } \\
\text { restaurant had it not offered the } \\
\text { daily deal. }\end{array}$ & 3.89 & 1.906 & 0.000 & -0.890 & \\
\hline $\begin{array}{l}\text { V6. I intend to visit this restaurant } \\
\text { again only if it offers a daily deal. }\end{array}$ & 4.40 & 1.842 & -0.322 & -0.865 & \\
\hline Perceived Value & & & & & - \\
\hline $\begin{array}{l}\text { V7. This restaurant would be a } \\
\text { good value even without the daily } \\
\text { deal. }\end{array}$ & 4.56 & 1.805 & -0.315 & -0.794 & \\
\hline Overall satisfaction & & & & & - \\
\hline $\begin{array}{l}\text { V8. Overall, I was very satisfied } \\
\text { with my dining experience at this } \\
\text { restaurant. }\end{array}$ & 4.73 & 1.791 & -0.390 & -0.731 & \\
\hline Intentional loyalty & & & & & 0.764 \\
\hline $\begin{array}{l}\text { V9. I will recommend this } \\
\text { restaurant to my family and friends. }\end{array}$ & 4.77 & 1.825 & -0.475 & -0.670 & \\
\hline $\begin{array}{l}\text { V10. I intend to visit this restaurant } \\
\text { again in the future even if I have to } \\
\text { pay full price. }\end{array}$ & 4.32 & 1.847 & -0.258 & -0.865 & \\
\hline
\end{tabular}

Source: Authors' estimations.

Table 3. Pearson's Correlation Coefficients between Variables

\begin{tabular}{|c|c|c|c|c|c|c|c|c|c|c|}
\hline & V1 & V2 & V3 & V4 & V5 & V6 & V7 & V8 & V9 & V10 \\
\hline V1 & 1 & & & & & & & & & \\
\hline V2 & $0.343 * * *$ & 1 & & & & & & & & \\
\hline V3 & $-0.506 * * *$ & $-0.330 * * *$ & 1 & & & & & & & \\
\hline V4 & $-0.409 * * *$ & $-0.291 * *$ & $0.369 * * *$ & 1 & & & & & & \\
\hline V5 & $0.405 * * *$ & $0.527 * * *$ & $-0.374 * * *$ & $-0.339 * * *$ & 1 & & & & & \\
\hline V6 & $0.341 * * *$ & $0.234 * *$ & $-0.239 * *$ & $-0.584 * * *$ & $0.484 * * *$ & 1 & & & & \\
\hline V7 & $0.408 * * *$ & $0.529 * * *$ & $-0.371 * * *$ & -0.113 & $0.527 * * *$ & $0.188^{*}$ & 1 & & & \\
\hline V8 & $0.468 * * *$ & $0.492 * * *$ & $-0.388 * * *$ & -0.154 & $0.630 * * *$ & $0.260 * *$ & $0.747 * * *$ & 1 & & \\
\hline V9 & $0.384 * * *$ & $0.522 * * *$ & $-0.425 * * *$ & $-0.234 * *$ & $0.457 * * *$ & $0.210^{* *}$ & $0.631 * * *$ & $0.645 * * *$ & 1 & \\
\hline V10 & $0.495 * * *$ & $0.468 * * *$ & $-0.449 * * *$ & $-0.359 * * *$ & $0.357 * * *$ & $0.225^{*}$ & $0.664 * * *$ & $0.606 * * *$ & $0.618 * * *$ & 1 \\
\hline
\end{tabular}

Source: Authors' estimations.

Notes: a) $* p<0.05, * * p<0.01$, *** $p<0.001$; b) the values equal to 1 on the diagonal consist of the correlation of a variable with itself. 


\section{Results}

Hierarchical regression analyses were conducted to test the hypothesis. Intention to repurchase and intention to recommend were specified as the dependent variables respectively. The results are shown in Tables 4 and 5. The demographic variables (i.e., gender, age, education, profession and income) were included in the analysis as control variables. As shown in Model 1 of Table 4, none of them was significant in explaining the variances of the dependent variables. To save space, subsequent models in Tables 4 and 5 only present statistically significant predictors.

Table 4. Regression Results of Predictors of Intention to Repurchase

\begin{tabular}{|c|c|c|c|c|c|c|c|c|c|c|}
\hline Models & Predictors & B & \begin{tabular}{|c|} 
Std. \\
Error
\end{tabular} & Beta & $\mathbf{t}$ & Sig. & $\mathbf{R}^{2}$ & $\begin{array}{c}\mathbf{R}^{2} \\
\text { Change }\end{array}$ & $\begin{array}{c}\mathbf{F} \\
\text { Change }\end{array}$ & $\begin{array}{c}\text { Sig. F } \\
\text { Change }\end{array}$ \\
\hline Model 1 & (Constant) & 2.605 & 1.497 & & 1.740 & 0.085 & 0.055 & 0.055 & 1.101 & 0.365 \\
\hline & Gender & 0.380 & 0.424 & 0.102 & 0.896 & 0.373 & & & & \\
\hline & Age & 0.085 & \begin{tabular}{|l|}
0.677 \\
\end{tabular} & 0.014 & 0.126 & 0.900 & & & & \\
\hline & Profession & 0.048 & 0.153 & 0.033 & 0.316 & 0.753 & & & & \\
\hline & Education & 0.036 & 0.284 & 0.014 & 0.127 & 0.899 & & & & \\
\hline & Salary & 0.246 & 0.175 & 0.164 & 1.406 & 0.163 & & & & \\
\hline & Salary & 0.246 & 0.175 & 0.164 & 1.406 & 0.163 & & & & \\
\hline Model 2 & (Constant) & 0.872 & 1.134 & & 0.769 & 0.444 & 0.486 & 0.431 & 38.617 & 0.000 \\
\hline & $\begin{array}{l}\text { V8 } \\
\text { Satisfaction }\end{array}$ & 0.240 & 0.118 & 0.232 & 2.029 & 0.045 & & & & \\
\hline & V7 Value & 0.493 & 0.115 & 0.482 & 4.273 & 0.000 & & & & \\
\hline Model 3 & (Constant) & 0.380 & 1.066 & & 0.356 & 0.722 & 0.562 & 0.075 & 7.721 & 0.001 \\
\hline & $\begin{array}{l}\text { V8 } \\
\text { Satisfaction }\end{array}$ & 0.181 & 0.112 & 0.175 & 1.618 & 0.109 & & & & \\
\hline & V7 Value & 0.475 & 0.109 & 0.464 & 4.354 & 0.000 & & & & \\
\hline & $\begin{array}{l}\text { V4 Think } \\
\text { Less }\end{array}$ & -0.219 & 0.070 & -0.236 & -3.115 & 0.002 & & & & \\
\hline Model 4 & (Constant) & 3.001 & 1.323 & & 2.268 & 0.026 & 0.605 & 0.032 & 3.492 & 0.035 \\
\hline & $\begin{array}{l}\text { V8 } \\
\text { Satisfaction }\end{array}$ & 0.260 & 0.121 & 0.252 & 2.157 & 0.034 & & & & \\
\hline & V7 Value & 0.455 & 0.111 & 0.445 & 4.108 & 0.000 & & & & \\
\hline & $\begin{array}{l}\text { V4 Think } \\
\text { Less }\end{array}$ & -0.250 & 0.086 & -0.270 & -2.903 & 0.005 & & & & \\
\hline & $\begin{array}{l}\text { V6 Return } \\
\text { with Deal }\end{array}$ & \begin{tabular}{|c|}
-0.242 \\
\end{tabular} & 0.107 & -0.242 & -2.254 & 0.027 & & & & \\
\hline
\end{tabular}

Source: Authors' estimations.

Note: Dependent variable: intention to repurchase.

The results revealed that satisfaction and perceived value had positive significant impact on intention to repurchase. Thus, hypotheses H1a and H2a were supported and the results were consistent with the literature. Hypothesis H3a was partially supported, because only one (V4) of the two variables representing service experience was significant. However, contrary to what was proposed, V4 had negative rather than positive impact on intention to repurchase. It seemed that if customers thought less of a restaurant because of its offering of daily deals, they may have higher intention to re-visit in the 
future. Neither of the two variables (V1 and V2) representing spending and ordering behavior was significant, thus hypothesis $\mathrm{H} 4 \mathrm{a}$ was rejected. Hypothesis H5a was partially supported. For the two variables representing deal proneness, only V6 was significant. Consistent with our expectation, the direction of the impact was negative. Thus, apparently customers who were more deal prone were less likely to return if they had to pay full price.

Similar to the results in Table 4, Table 5 revealed that the demographic variables did not influence the respondents' daily deal recommendation intention. Satisfaction and perceived value were significant and strong predictors of intention to recommend, with $\mathrm{R}^{2}$ value of 0.477 . Therefore, hypotheses $\mathrm{H} 1 \mathrm{~b}$ and $\mathrm{H} 2 \mathrm{~b}$ were supported. However, the variables representing spending and ordering behaviors (V1 and V2) and service experience (V3 and V4) turned out to be insignificant, thus hypotheses $\mathrm{H} 3 \mathrm{~b}$ and $\mathrm{H} 4 \mathrm{~b}$ were rejected.

Table 5. Regression Results of Predictors of Intention to Recommend

\begin{tabular}{|l|l|c|c|c|c|c|c|c|c|c|}
\hline Models & Predictors & B & $\begin{array}{c}\text { Std. } \\
\text { Error }\end{array}$ & Beta & $\mathbf{t}$ & Sig. & $\mathbf{R}^{2}$ & $\begin{array}{c}\mathbf{R}^{2} \\
\text { Change }\end{array}$ & $\begin{array}{c}\text { F } \\
\text { Change }\end{array}$ & $\begin{array}{c}\text { Sig. F } \\
\text { Change }\end{array}$ \\
\hline Model 1 & Constant) & 1.922 & 1.484 & & 1.295 & 0.199 & 0.049 & 0.049 & 0.961 & 0.446 \\
\hline & Gender & 0.247 & 0.421 & 0.067 & 0.587 & 0.558 & & & & \\
\hline & Age & 0.464 & 0.672 & 0.076 & 0.690 & 0.492 & & & & \\
\hline & Profession & 0.188 & 0.152 & 0.129 & 1.239 & 0.218 & & & & \\
\hline & Education & 0.350 & 0.282 & 0.138 & 1.241 & 0.218 & & & & \\
\hline & Salary & 0.028 & 0.174 & 0.019 & 0.159 & 0.874 & & & & \\
\hline Model 2 & Constant) & 0.283 & 1.130 & & 0.251 & 0.803 & 0.477 & 0.428 & 37.656 & 0.000 \\
\hline & $\begin{array}{l}\text { V8 } \\
\text { Satisfaction }\end{array}$ & 0.391 & 0.118 & 0.383 & 3.317 & 0.001 & & & & \\
\hline & V7 Value & 0.341 & 0.115 & 0.337 & 2.963 & 0.004 & & & & \\
\hline
\end{tabular}

Source: Authors' estimations.

Note: Dependent variable: intention to recommend.

\section{Discussion and Implication}

Zhang et al. (2013) called for more study in group buying consumer behavior by including additional variables that were relevant. The current study echoed this call by examining several variables that were pertinent to group buying customers' experience. Consistent with current theory, the study found that the most important and reliable drivers of customer loyalty were satisfaction and perceived value. However, as found by Kimes and Dholakia (2011), daily deal purchasers were more coupon prone than non-purchasers, indicating that the former were more sensitive to price. Therefore, the recipe for attracting their repeat patronage is by offering value for money, as manifested by the highest standardized beta coefficient of perceived value among all of the predictors (as shown in Table 4).

The study incorporated two service experience variables that were unique to group buying. First, the results suggested that V3 was not a significant predictor of customer loyalty, indicating that second class citizen treatment was not an issue that could possibly impair customer loyalty. However, as shown in Table 2, the mean of V3 was 4.30, indicating that such unsatisfactory treatment was not 
uncommon among customers. Further research is required to resolve the puzzle. Second, interesting and unexpected result was revealed for V4, which had negative impact on intention to repurchase. The results suggested that customers who thought less of a restaurant due to its offering of daily deals were more likely to re-visit in the future. A possible explanation was that restaurants may previously have a premium brand image and was prohibitive to the mass market. Daily deal offerings broadened the market for these restaurants and made them approachable to more customers. In addition, offering discounts may give customers a signal, suggesting that these restaurants were, in fact, not such upscale brands as they were previously considered to be. Thus, customers may think less of the restaurants offering daily deals. However, given satisfactory services and value for money, customers may still have the intention to return even if they have to pay full price. If this justification could be confirmed, it may bring about an intriguing situation that businesses may need to face. That is, while daily deals could bring in more customers, the erosion of brand image may be a potential by-product.

For spending and ordering behavior, both V1 (Spend More) and V2 (Order More) were insignificant. However, they were positively correlated with key service evaluation variables (e.g., satisfaction, perceived value and loyalty intention). In addition, the mean of V2 (4.41) was higher than that of V1 (4.00). The results suggested that daily deal customers were less likely to spend more than usually, but they may order more items within their habitual budget, which was facilitated by the discounts of daily deals. The results tentatively suggest that for restaurants counting on daily deals to bring in repeat businesses, they should focus on providing favorable service experience, customer satisfaction and perceived value and at the same time allowing customers to enjoy a meal sticking to their usual budget and ordering habit.

Finally, the results revealed that deal proneness had negative impact on intention to return. Consequently, customers who were more deal prone were less likely to return if they had to pay full price. Given the deep discounts that are common in daily deals, this finding alerts businesses to the potential erosion of such practice on profitability. As explicated by Edelman et al. (2014), discounts are likely to be profitable if they could attract new customers who regularly return and pay full price. An issue of concern is cannibalization of existing full-paying customers by deal prone customers (Kimes and Dholakia 2011). Even if the incremental revenues from new customers outweigh the cannibalization effect, restaurants may have to face the re-positioning of their brands (as discussed above) and consider if this is what they want.

\section{Conclusions}

This study examined predictors of customer loyalty in the context of online group buying in the restaurant industry. Besides perceived value and satisfaction, which were well-established predictors in the marketing literature, the study included several variables that reflected the unique aspects of customer experience of the daily deal offerings. Specifically, the results indicated that customers with 
higher intention to repurchase were those who were less deal prone and those who thought less of a restaurant because of its offering of daily deals.

However, given the convenience sample employed in the study, the results may be biased and thus should be considered as exploratory. Future research could consolidate the investigation by collecting a more representative sample. Moreover, most of the predictors in the current study contained only one indicator, which prevented an examination of the scale reliability. Multiple-indicator constructs need to be developed to create scales with sound construct validity, thus more advanced statistical methods (e.g., SEM) could be used to corroborate and extend existing theory.

\section{References}

Back K, Parks SC (2003) A brand loyalty model involving cognitive, affective, and conative brand loyalty and customer satisfaction. Journal of Hospitality \& Tourism Research 27(4): 419-435.

Baker DA, Crompton JL (2000) Quality, satisfaction and behavioral intentions. Annals of Tourism Research 27(3): 785-804.

CNNIC - China Internet Network Information Center (2015) Statistical Report of the Internet Development in China. Retrieved from http://goo.gl/47JRoc. [Accessed: 5 March 2015]

Edelman B, Jaffe S, Kominers S (2014) To groupon or not to groupon: the profitability of deep discounts. Working Paper. Retrieved from http://goo.gl/a5 Hsmc. [Accessed: 5 April 2015]

Enfodesk (2013) 2012 Group buying industry in China white paper. Retrieved from http://goo.gl/pmDxw3. [Accessed: 25 February 2015]

Enfodesk (2014) Quarterly barometer of the group buying market in china: 3 rd quarter, 2014. Retrieved from http://goo.gl/pmDxw3. [Accessed: 25 February 2015]

Grewal D, Ailawadi KL, Gauri D, Hall K, Kopalle P, Robertson JR (2011) Innovations in retail pricing and promotions. Journal of Retailing 87(Supplement 1): 43-52.

Kimes SE, Dholakia U (2011) Restaurant daily deals: customers' responses to social couponing. Cornell Hospitality Report 11(20): 6-18.

Knox SD, Denison TJ (2000) Store loyalty: its impact on retail revenue. an empirical study of purchasing behavior in the UK. Journal of Retailing and Consumer Services 7: 33-45.

Lee I, Lee K (2012) Social shopping promotions from a social merchant's perspective. Business Horizons 55: 441-451.

Lewis, M (2007) Stepwise versus hierarchical regression: Pros and cons. Paper presented at the Annual Meeting of the Southwest Educational Research Association, 7 February 2007. San Antonio, USA.

Li X, Yang J, Liu X (2012) Impact of time pressure and reference group on customer purchase intention in group-buying on the web. China Soft Science 4: 117-124.

Ning L, Zhang X (2011) Empirical analysis on the influencing factors of impulse purchase intention in online group-buying. Journal of Fujian Normal University (Philosophy and Social Sciences Edition) 6: 13-18.

Parsons AG, Ballantine PW, Ali A, Grey H (2014) Deal is on! Why people buy from daily deal websites. Journal of Retailing and Consumer Services 21: 37-42. 
Petrick JF (2004) The roles of quality, value, and satisfaction in predicting cruise passengers' behavioral intentions. Journal of Travel Research 42(4): 397-407.

Reinartz W, Thomas JS, Bascou G (2008) Investigating cross-buying and customer loyalty. Journal of Interactive Marketing 22(1): 5-20.

Tan Y (2013) Research on the group buying behavioral characteristics of university students. Theory Research 17: 322-323.

Wang H, Liu S (2013) A review of the literature of online group-buying and prospects. Foreign Economics \& Management 35(7): 73-80.

Wu J, Kimes SE, Dholakia U (2012) Restaurant daily deals: The operator experience. Cornell Hospitality Report 12(16): 6-18.

Zhang F, Zhang G, Yang S, Zhu W (2012) Analysis of willingness to buy in the consumer network. Science-Technology and Management 14(3): 33-37.

Zhang Z, Lu X (2009) Consumer willingness to participate in group buying: an investigation based on the TAM model and perceived risk. Marketing Herald 1: 13-19.

Zhang Z, Zhang Z, Wang F, Law R, Li D (2013) Factors influencing the effectiveness of online group buying in the restaurant industry. International Journal of Hospitality Management 35: 237-245. 